\title{
The associative polymer flooding: an experimental study
}

\author{
Rustem Abirov ${ }^{1} \cdot$ Aleksandr P. Ivakhnenko $^{1} \cdot$ Zhandos Abirov $^{2} \cdot$ Nikolai A. Eremin $^{3}$ (D)
}

Received: 26 March 2019 / Accepted: 28 May 2019 / Published online: 4 June 2019

(c) The Author(s) 2019

\begin{abstract}
This study investigates the sandpack displacement of low viscosity oil (1.68 cP) by brine and aqueous solutions of associative polymers. Polymer flooding has been thoroughly investigated in many laboratory and field tests. Polymer flooding is one of the most widely used enhanced oil recovery (EOR) methods. The method of polymer flooding is not used for development of oil fields with gas caps, fractured reservoirs, high permeability and active bottom-water drive. In the application of polymer flooding, coefficient of oil recovery is increased by 3-10\%. Hydrolyzed polymers undergo the significant thermal and chemical degradation at high temperature and salinity. In recent years, researchers have turned their attention to associative polymers. An application of associative polymers to withstand degradation in high temperature and high salinity conditions can enhance oil recovery in high heterogeneous fields. This article presents the results of studies of oil displacement by associative polymers in a two-layer core model. In laboratory studies, the core selected from a sandy reservoir of the South Turgay Basin of the Republic of Kazakhstan was used. Solutions of the following polymers were studied: hydrolyzed polyacrylamide (HPAM) and associative polymer. The physicochemical conditions of the experiments corresponded to the reservoir conditions of the sand layer of the South Turgay Basin: temperature of $82{ }^{\circ} \mathrm{C}$ and the salinity of the brine $92,000 \mathrm{ppm}$. Experiments revealed that the associative polymer is more stable in simulated reservoir conditions than the HPAM polymer. Associative polymer flooding was recommended for pilot testing at the reservoir of the South Turgay Basin.
\end{abstract}

Keywords Associative polymer flooding $\cdot$ Enhanced oil recovery $\cdot$ EOR $\cdot$ Core flooding $\cdot$ Polymer flooding

$\begin{array}{ll}\text { Abbreviations } \\ \text { AMPS } & 2 \text {-Acrylomide-2-methylopropane sulfonate } \\ \text { EOR } & \text { Enhanced oil recovery } \\ n \text {-VP } & n \text {-Vinyl pyrrolidone } \\ S_{\mathrm{wi}} & \text { Initial water saturation } \\ \text { PV } & \text { Pore volume } \\ \text { HPAM } & \text { Hydrolyzed polyacrylamide } \\ S_{\mathrm{o}} & \text { Oil saturation }\end{array}$

Nikolai A. Eremin

ermn@mail.ru

Rustem Abirov

rustabi@gmail.com

Aleksandr P. Ivakhnenko

energy.petroleum@gmail.com

Zhandos Abirov

zhabirov@snf-group.kz

Kazakh-British Technical University, Almaty, Kazakhstan

2 SNF-Vostok, Almaty, Kazakhstan

3 The Oil and Gas Research Institute of Russian Academy of Sciences, The Gubkin Russian State University of Oil and Gas, Moscow, Russia
WF Water flooding

PF Polymer flooding

OOIP Original oil in place

TDS Total dissolved solids

\section{Introduction}

Polymer flooding has been thoroughly investigated in many laboratory and field tests. Polymer flooding is one of the most widely used the enhanced oil recovery (EOR) methods (Basnieva et al. 1994; Eremin and Nazarova 2001; Lake 1996). The method of polymer flooding is not used for development of oil fields with gas caps, fractured reservoirs, high permeability and active bottom-water drive. In the application of polymer flooding, coefficient of oil recovery is increased by $3-10 \%$.

Polymers are substances of high molecular mass of the order $10^{4}-10^{6}$. This substance can considerably increase water viscosity. When polymer is applied, the ratio of the coefficients of mobility of water and oil decreases and, respectively, the sweep efficiency factor increases. The ratio 
of the coefficients of mobility of water and oil is presented as:

$M=\lambda_{\text {water }} / \lambda_{\text {oil }}$,

Coefficients of mobility water and oil are

$\lambda_{i}=K_{i} / \mu_{i}, \quad i=$ water, oil;

where $K_{i}$ phase permeability $i$-fluid and $\mu_{i}$ reservoir viscosity $i$-fluid.

Hydrolyzed polymer has a long history of use as a chemical agent for polymer flooding. The range of application of the hydrolyzed polymer as a thickener is limited due to its chemical degradation at high temperature and salinity. The viscosity of solutions of traditional polymers significantly changes during the decomposition of the polymer at high temperature and mineralization conditions (Lake 1996; Leblanc et al. 2015).

For regular HPAM polymers, an increase in temperature leads to an increase in the hydrolysis of acrylamide moieties generating a higher charge density of anionic functionalities along the polymer backbone. Polyacrylamides can be modified with various monomers to protect them from degradation. The incorporation of the anionic monomer 2-acrylomido-2-methylpropane sulfonate (AMPS) increases the tolerance to divalent ions (Levitt and Pope 2008), but this monomer does not protect the acrylamide from thermal hydrolysis (Moradi-Araghi et al. 1987). The tolerated $\mathrm{Ca}^{2+}$ concentration was found to be less than $2000 \mathrm{ppm}$ for a polymer containing 20-30\% AMPS monomer, which is still significantly lower than the concentration $\mathrm{Ca}^{2+}$ found in some high-saline carbonate reservoirs. The incorporation of $n$-vinyl pyrrolidone ( $n$-VP) effectively protects the acrylamide groups against the thermal hydrolysis. Earlier stability tests on $n$-VP.AM co-polymers in a weight ratio of 50:50 have shown this polymer to have long-term stability in seawater at $120^{\circ} \mathrm{C}$ (Doe et al. 1987).

New types of polymers are used for oil reservoirs with high temperature and salinity. The published literature reports many innovative associative polymers (Akbari et al. 2017; Aktas et al. 2008; Alexis et al. 2016; Azad and Trivedi 2017; Denney 2012; Gogoi and Gogoi 2019; Han et al. 2018; $\mathrm{Lv}$ et al. 2017). Projects of an associative polymer flooding are currently ongoing in high salinity $(200 \mathrm{~g} / \mathrm{l})$, high temperature and hardness conditions (Al-Taq et al. 2007;
Cheraghian et al. 2015; Dupuis et al. 2010; Guo et al. 2018; Nunez Garcia et al. 2010). The key problem of the associative polymer flooding connects with high temperature rather than high salinity (Delamaide 2018; Reichenbach-Klinke et al. 2016). Associative polymers undergo decomposition at higher temperatures and salinity than traditional polymers (Tripathi et al. 2006; Skauge et al. 2018). The associative polymer solution improves the water-oil mobility ratio. The sweep efficiency is the key factor that determines the success of an associative polymer flooding. The research aims were to study oil recovery applying associative polymerSuperpusher SV of SNF company at $82{ }^{\circ} \mathrm{C}$ temperature and brine salinity 92,000 ppm under the conditions of South Turgay Basin reservoir, the Republic of Kazakhstan. The conditions of this reservoir were simulated in experiments, using the core flooding equipment. The study has been made with three different types of the core polymer flooding: the HPAM polymer, Superpusher SV, pre-flush slug with the Superpusher SV followed by a HPAM as the main slug.

\section{Materials and method}

Two polymer types were used (see Table 1)—associative polymer Superpusher ${ }^{\mathrm{TM}}$ of SNF Company, and partially hydrolyzed polyacrylamide HPAM. Polymer mixtures with the concentration of $4000 \mathrm{ppm}$ were mixed with the water with the mineralization $0.5 \mathrm{mg} / \mathrm{l}$ of $\mathrm{NaCl}$ and hydrated $24 \mathrm{~h}$ to generate the mother solution using magnetic stirrer. First polymer solution was the HPAM and water solution. Second was Superpusher and technical water solution.

For the experiment, a two-layer sandpack core model was prepared with an upper layer permeability -7 Darcy and a lower layer permeability-2.8 Darcy. The upper permeable layer had a grain size of $500 \mu \mathrm{m}$; the lower permeable layer had a grain size of $125 \mu \mathrm{m}$. The sandpack core model was made of two layers, taking into account the heterogeneity of the studied formation. The core sample was represented by sandstone deposited in river sedimentation conditions.

The sandpack core samples were saturated with brine which had water salinity $90-92 \mathrm{~g} / \mathrm{l}$ of $\mathrm{CaCl}_{2}$. Porosity measured by weight method was about $27 \%$. All studies were performed at room temperature. Samples of oil had properties similar to the field oil. Oil viscosity ranged from 1 to
Table 1 Sandpack core properties

\begin{tabular}{lllllll}
\hline Core ID & Core length $(\mathrm{m})$ & $\begin{array}{l}\text { Core diam- } \\
\text { eter }(\mathrm{m})\end{array}$ & Porosity $(\%)$ & $\begin{array}{l}\text { Permeability } \\
(\mathrm{mD})\end{array}$ & $S_{\mathrm{wi}}(\%)$ & $\begin{array}{l}\text { Aging } \\
\text { time } \\
(\text { day })\end{array}$ \\
\hline A1 & 0.04 & 0.03 & 27 & 2549 & 44 & 2 \\
A2 & 0.04 & 0.03 & 24 & 2549 & 48 & 2 \\
A3 & 0.04 & 0.03 & 25 & 2549 & 45 & 2 \\
\hline
\end{tabular}


$1.682 \mathrm{mPa} \mathrm{s}\left(1.6 \mathrm{mPa} \mathrm{s}\right.$ at $\left.60{ }^{\circ} \mathrm{C}\right)$ and density of oil was $0.7851 \mathrm{~g} / \mathrm{cm}^{3}$. Before the experiment, the core samples were saturated with salt water and oil. Water was injected at a rate of $0.1 \mathrm{cc} / \mathrm{min}$. The device layout is shown in Fig. 1, and the equipment installation is shown in Fig. 2.

\section{Sandpack preparation}

Brine samples were saturated with formation water. Base core permeability was measured at three different flow rates. The sandpack core samples were kept for 2 days at $500{ }^{\circ} \mathrm{C}$ to establish ionic equilibrium between the rock and the formation water. Weight method was applied to measure effective porosity. To establish the initial water saturation in the laboratory core samples, their impregnation with dead crude oil was carried out. Oil impregnation was completed when the minimum water saturation was reached and no water was released from the core. Sandpack core properties are given in Table 1.

\section{Experimental study}

A coreholder equipment was used in the flooding experiments. The sandpack core sample was placed in the coreholder with a confining pressure of 20 bar or $2 \mathrm{MPa}$ according to axial stress of the depth that core prepared.

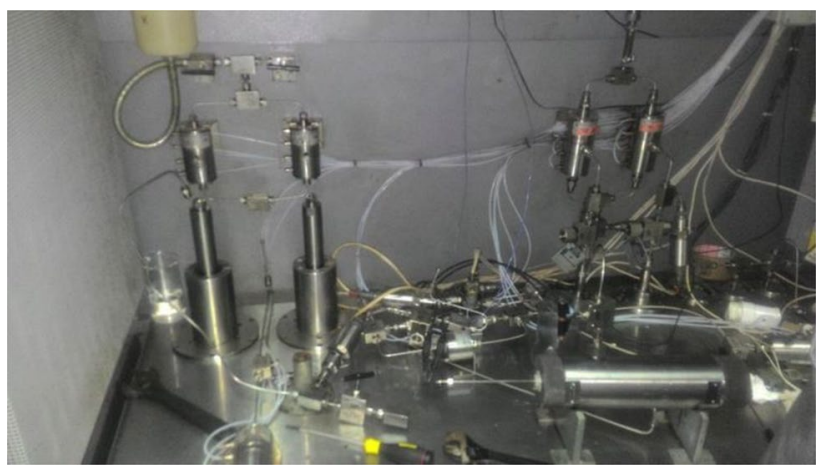

Fig. 2 Core flooding experiment equipment picture

Two types of polymer were used in experiments partially hydrolyzed polyacrylamide HPAM and Superpusher ${ }^{\mathrm{TM}}$ associative polymer was used. Table 2 gives the description of the 3 core floods that have had tested.

\section{Waterflood tests}

During the experiment, the sandpack core sample was placed to the coreholder in the confining pressure $2 \mathrm{MPa}$. The waterflood saturation was performed at rate $0.1 \mathrm{cc} / \mathrm{min}$ at temperature of $50^{\circ} \mathrm{C}$. The pressure drop across the sandpack core sample was carefully monitored in all experiments.

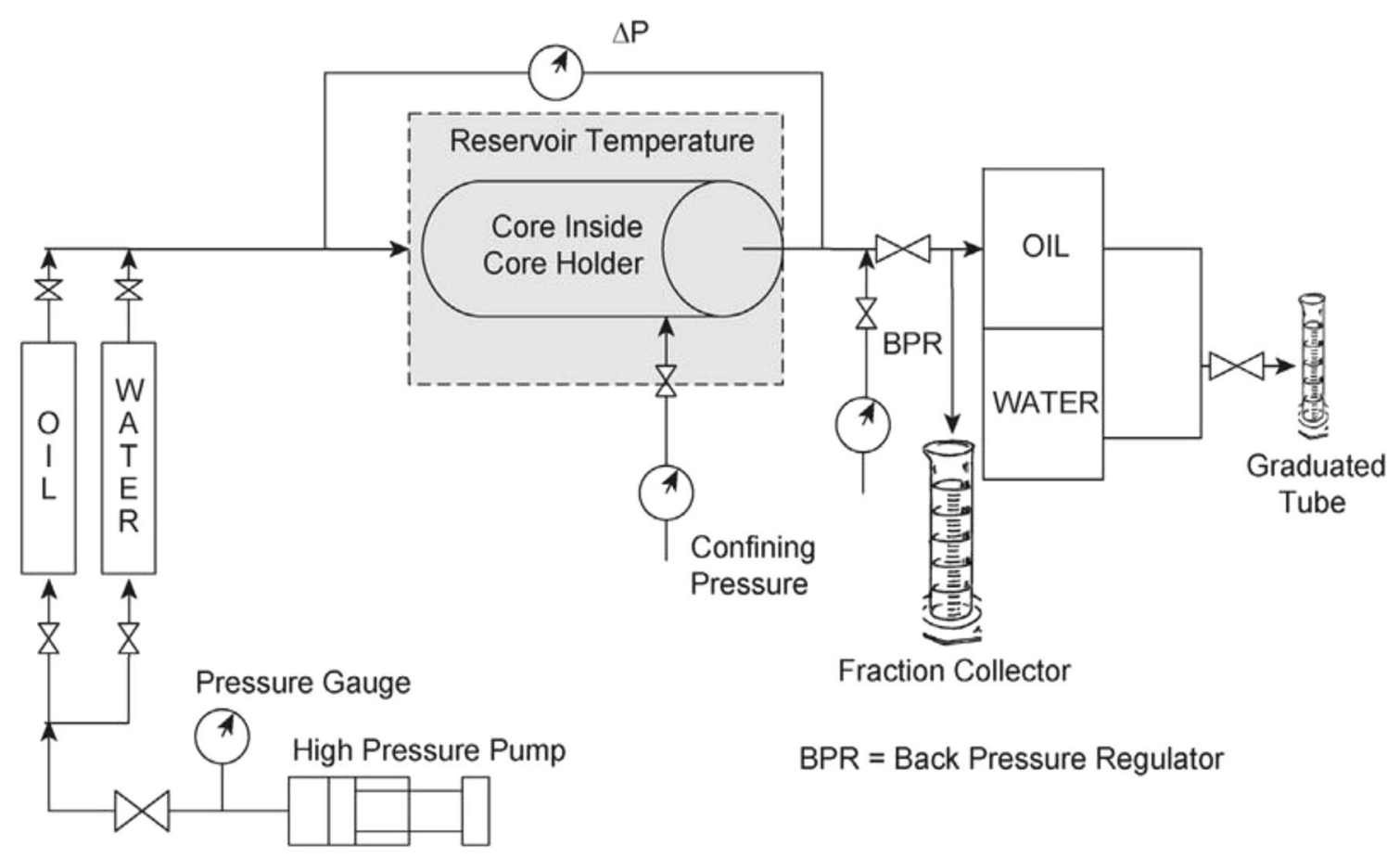

Fig. 1 Schematic diagram of a two-phase core flooding experiment setup 
The first waterflood test was a continuous injection of formation water (high salinity brine) to remaining oil saturation after water flooding. The test was completed when a high and stable water cut was achieved. The produced oil was collected using a fractional collector, and the oil recovery was determined as the percentage of oil in place (percentage of OOIP). The effluent samples were collected regularly and $\mathrm{pH}$ was measured and recorded. Table 3 shows the experimental layout of core displacement experiments.

\section{Results}

Based on Fig. 3, the pressure drop for $1 \mathrm{cc}$ of Superpusher followed by the $20 \mathrm{cc}$ of the HPAM, rapidly increased reaching about $0.3 \mathrm{MPa}$ within 11.5 pore volumes injected and then become more stable. This clearly indicates that the reluctant in situ viscosity is very high possibly due to very strong association in tight pores.

In Test 2, only HPAM was injected to the sandpack sample. In plot for the Test 2, pressure constantly rose from 0.1 to $10 \mathrm{cc}$. After that, occurs breakthrough occurs and pressure becomes stable at about $11 \mathrm{cc}$. Curve showed more stable front according to pressure curve (Fig. 4).

As we can see in this plot that behavior of the following flood in sandpack is different from the first and second experiments. As we can see that breakthrough occurs later than in second experiment. Also we can see fall of the pressure after the breakthrough that occurs at about $18 \mathrm{cc}$ of volume (Fig. 5).

Figure 6 represents the oil recovery plot corresponding to Test 1 flood. The initial oil saturation was $55 \%$ using a

Table 2 Description of polymer-oil displacement experiments

\begin{tabular}{llllllll}
\hline Flood no. & Polymer/concentration & $\mu_{\mathrm{o}}, \mathrm{cP}$ & $T,{ }^{\circ} \mathrm{C}$ & Salinity $(\mathrm{g} / \mathrm{l})$ & Porous media & Type of polymer & $k_{\text {brine }}, \mathrm{D}$ \\
\hline 1 & Superpusher-HPAM/400 ppm & $1.6832\left(60^{\circ} \mathrm{C}\right)$ & 82 & 92 & Sandpack & Associative 0.1 of PV, & 2.549 \\
& & & & & & HPAM 0.3 of PV \\
2 & Superpusher/400 ppm & $1.6832\left(60^{\circ} \mathrm{C}\right)$ & 82 & 92 & Sandpack & Associative 0.4 of PV & 2.549 \\
3 & HPAM/400 ppm & $1.6832\left(60^{\circ} \mathrm{C}\right)$ & 82 & 92 & Sandpack & HPAM 0.4 of PV & 2.549 \\
\hline
\end{tabular}

$\mu_{\mathrm{o}}$ viscosity of oil, $T$ temperature, $T D S$ total dissolved solution, $k_{\text {brine }}$ permeability of brine, $P V$ pore volume

Table 3 Experimental layout of core displacement study at $82{ }^{\circ} \mathrm{C}$

Fig. 3 Test 1 flood injection behavior: HPAM Superpusher $1 \mathrm{cc}$ and HPAM $20 \mathrm{cc}$

\begin{tabular}{lllllll}
\hline Test & Core ID & First flood & $\begin{array}{l}\text { Recovery }(\% \\
\text { OOIP })\end{array}$ & Polymer flood & $\begin{array}{l}\text { Recovery }(\% \\
\text { OOIP })\end{array}$ & Crude type \\
\hline Test 1 & A1 & Fresh water & 20.8 & $\begin{array}{l}\text { Superpusher 1 cc, } \\
\text { HPAM 20 cc }\end{array}$ & 4.76 & A \\
Test 2 & A2 & Fresh Water & 28.66 & HPAM, 20 cc & 5.85 & A \\
Test 3 & A3 & Fresh Water & 16.7 & Superpusher, 20 cc & 6.52 & A \\
\hline
\end{tabular}

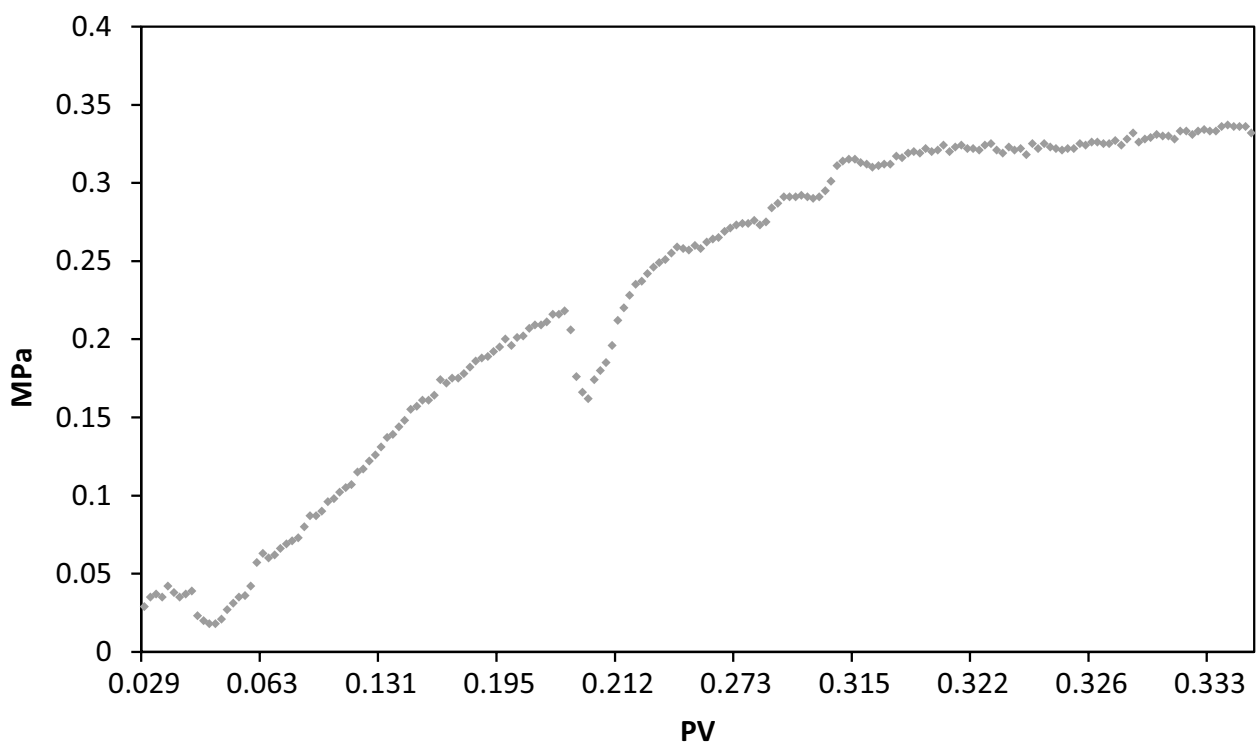




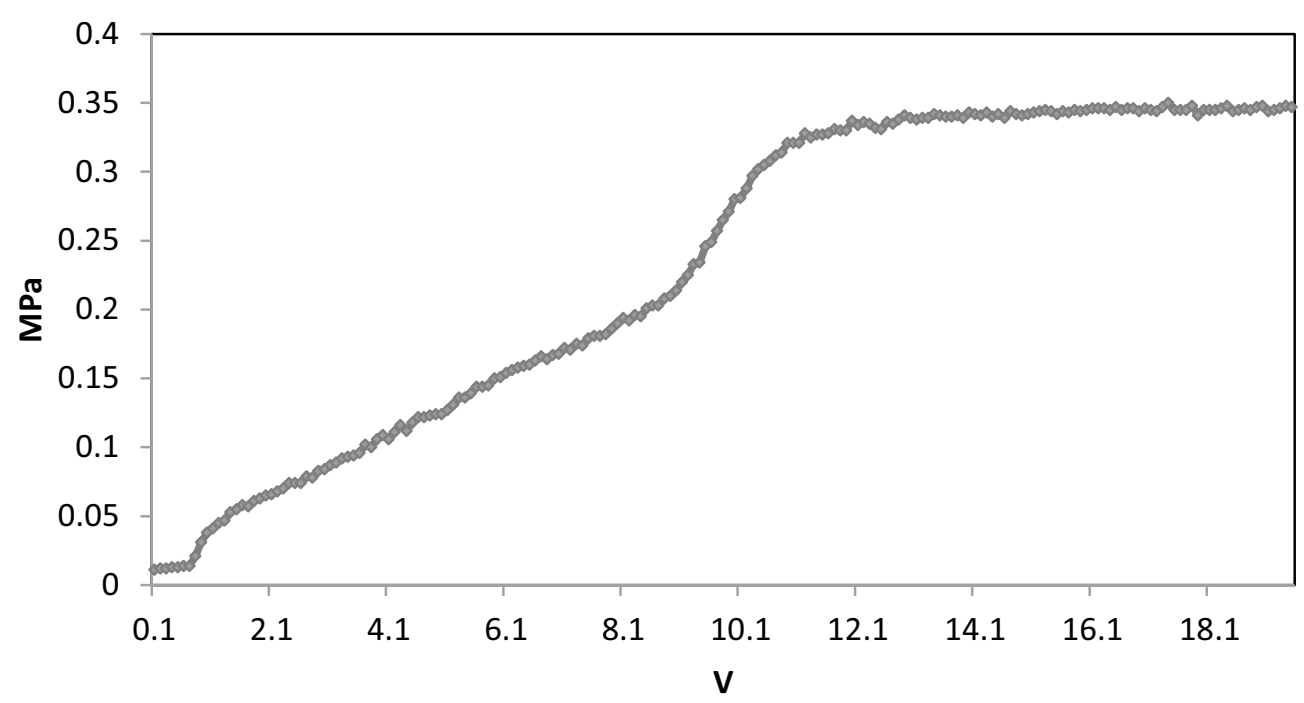

Fig. 4 Test 2 flood injection behavior: HPAM

Fig. 5 Test 3 flood injection behavior: Superpusher

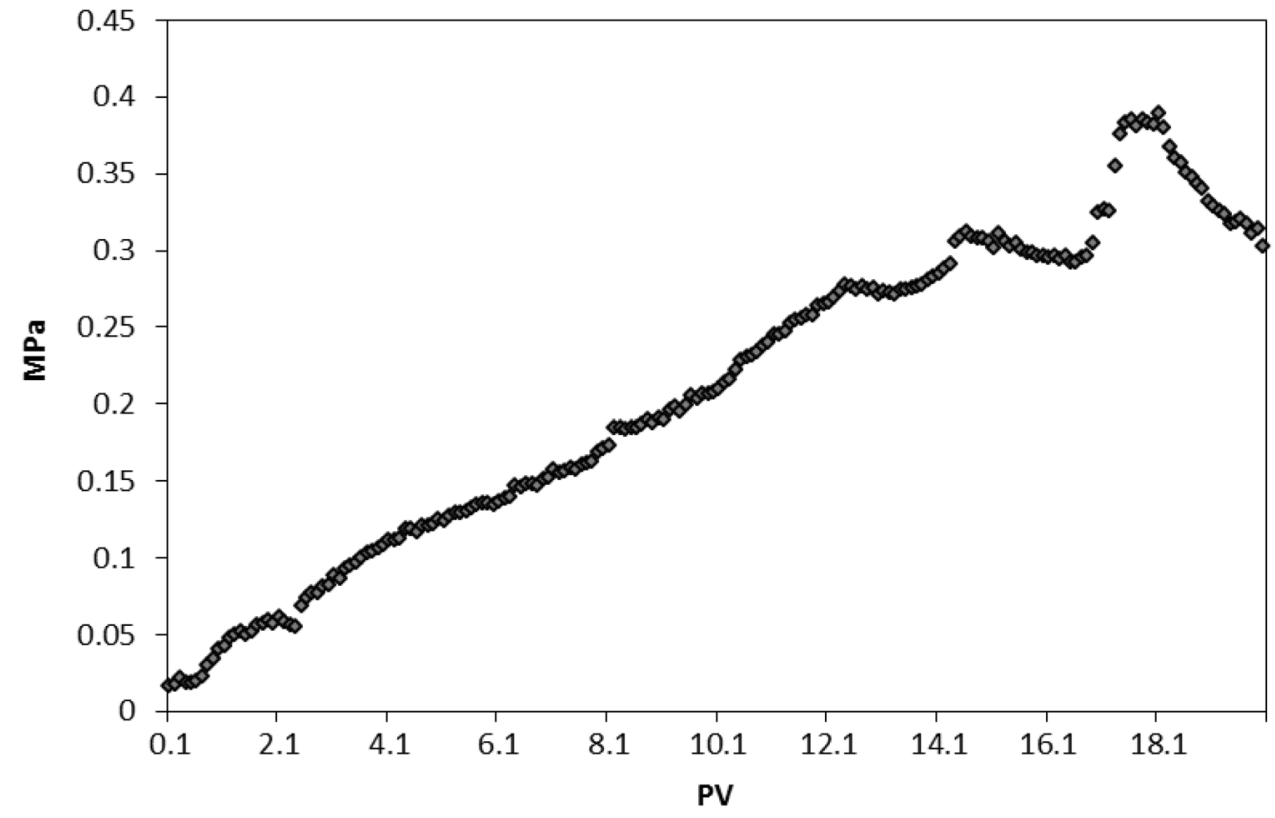

$1.6 \mathrm{cP}$ oil. A waterflood was initiated, and secondary oil recovery was continued for $20 \mathrm{cc}$ until the remaining oil saturation in the sandpack was about $45.7 \%$. HPAM polymer solution with pre-conditioning Superpusher slug with $1 \mathrm{cc}$ volume, polymer solution was used to start the tertiary oil recovery process. The oil bank breaks through at about $26 \mathrm{cc}$ indicated by the marked increase in oil cut from 0.1 to $0.5 \%$. The incremental oil recovery is about $20 \%$ after waterflooding and the remaining oil saturation after the polymer flood is approximately $4.76 \%$.

Figure 7 shows the oil recovery plot for Flood \#2 where partially 20-30\% hydrolyzed polymer was used for tertiary oil recovery process. Similar to Flood \#1, the sandpack was oil flooded and waterflooded and the tertiary polymer flooding was initiated at around $20 \mathrm{cc}$. The remaining oil saturation after waterflooding for this test was 39\%. An oil bank due to polymer started following waterflooding. The incremental oil recovery is about 6\% higher than in Flood test \#1.

Figure 8 shows the secondary polymer flood oil recovery in sandpack with associative polymer Superpusher SV was used. These floods were run with the same conditions as first two ones at $82{ }^{\circ} \mathrm{C}$ with $1.63 \mathrm{cP}$ oil. The total cumulative oil recovery for both the floods is about $22.5 \%$ of the initial oil saturation. The flood with associated polymer demonstrated 
Fig. 6 Oil recovery plot for test flood 1

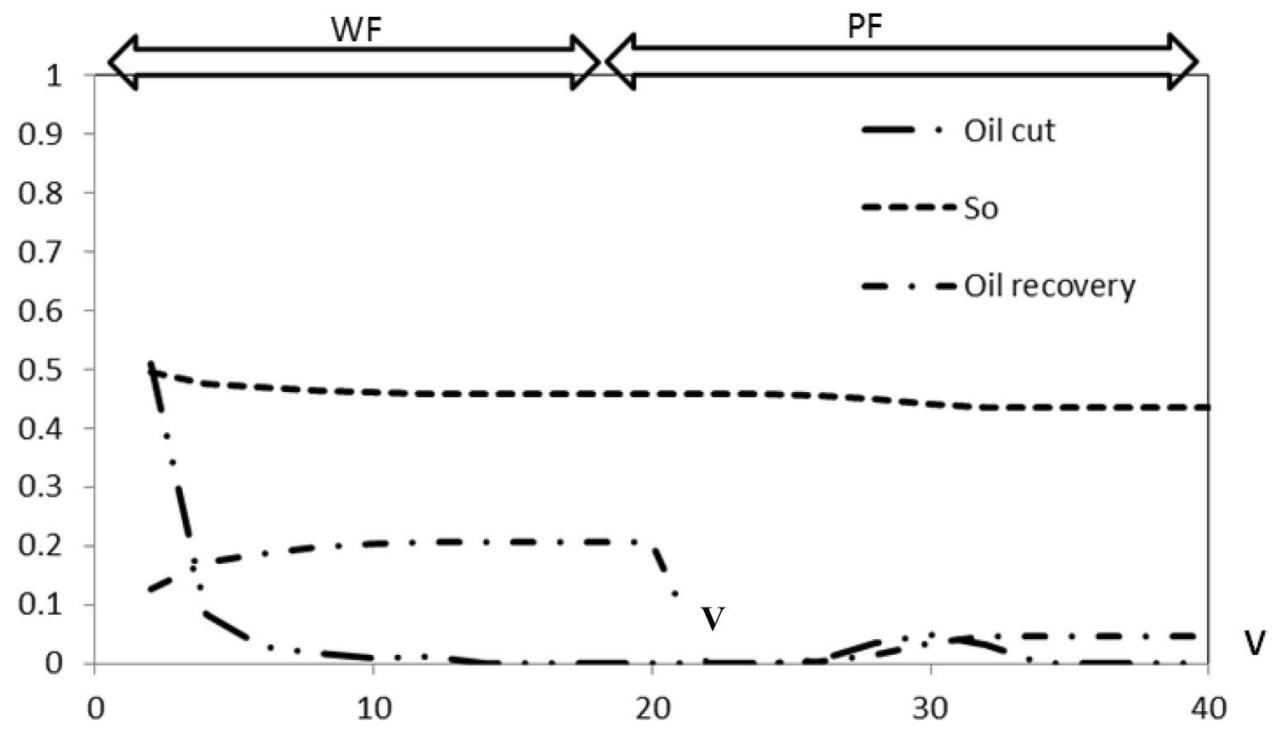

Fig. 7 Oil recovery plot for test flood 2

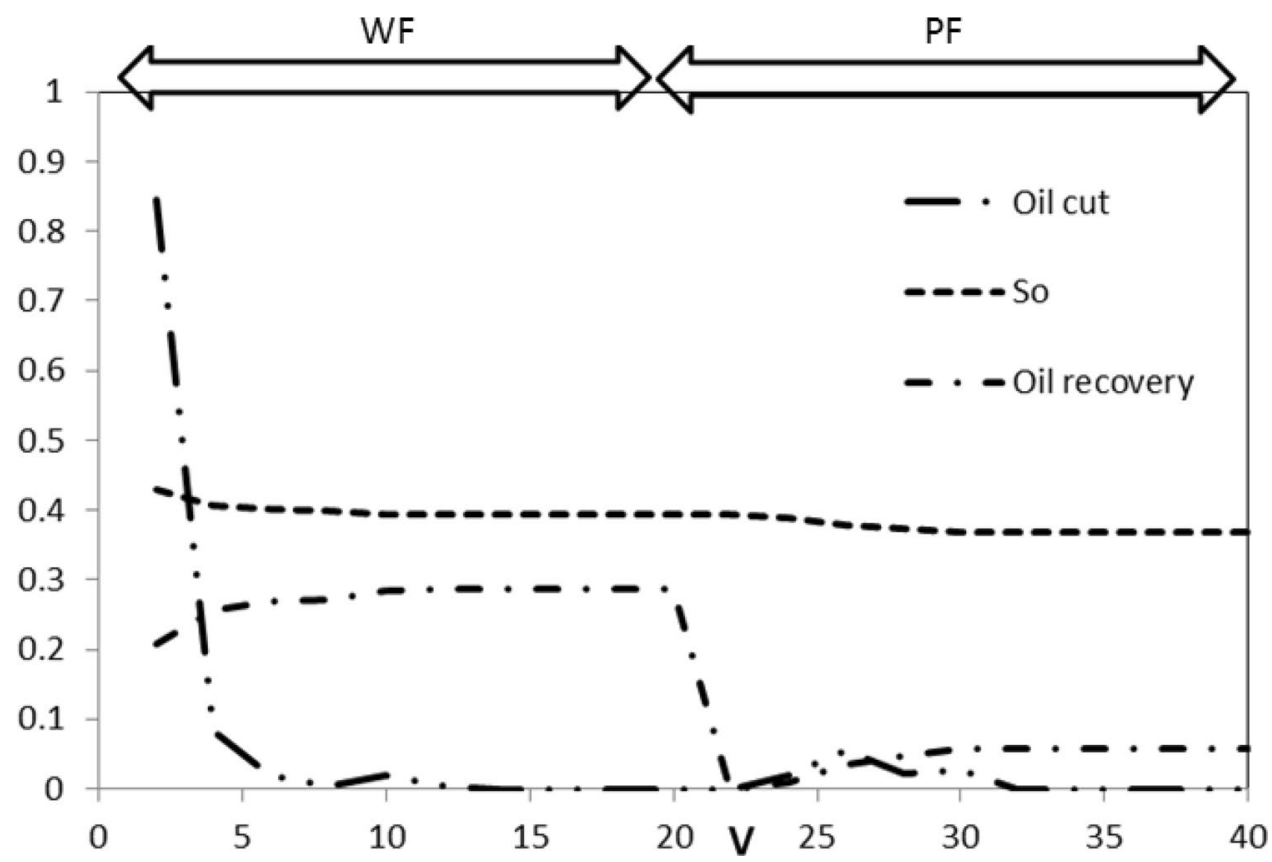

higher recovery compared to other floods for the $0.67 \%$ for the second flood and $1.76 \%$ for the first flood test. The oil bank breaks through at about $4 \mathrm{cc}$ in the polymer only flood, indicated by the marked increase in oil cut from 2 to $6.3 \%$.

\section{Discussion}

Polymer viscosity has to be taken to consideration in further research. The viscosity of each type polymer especially if we injecting pre-flush of one them should be considered. Also the lack of natural sandstone cores from the researched oilfield is making investigation of polymer pre-flush not very accurate. Effect of the low salinity and lower viscosity of associated polymer for the pre-flush should be considered for future research.

\section{Conclusion}

Based upon the conducted experiments, the following conclusions are drawn:

1. Associative polymer can be effective even in not very high temperature $\left(82^{\circ} \mathrm{C}\right)$ and high salinity $(92,000 \mathrm{ppm})$. 
Fig. 8 Oil recovery plot for test flood 3

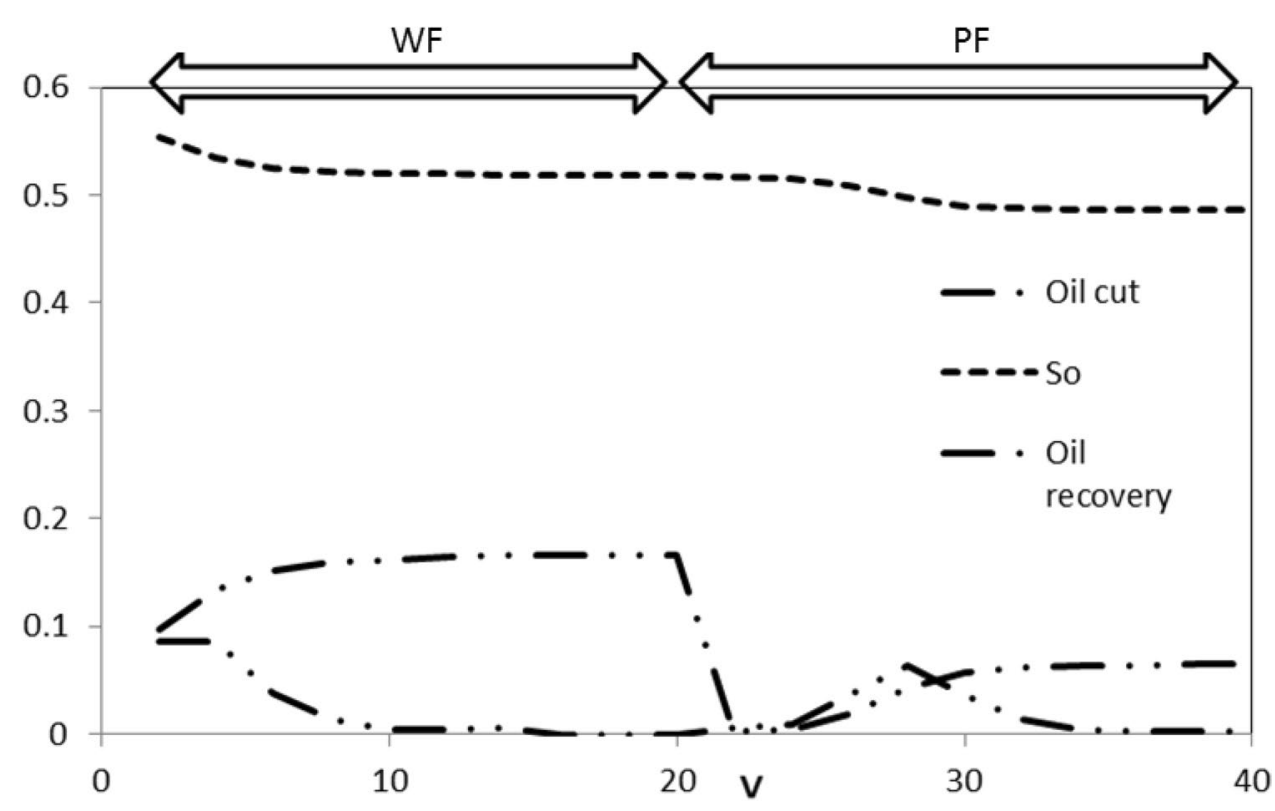

2. Pre-flush slug's viscosity should be considered prior the experiments. In our case, it has not worked; however, above consideration should be tested.

3. In the conditions of modeled field $82^{\circ} \mathrm{C}$ and $92,000 \mathrm{ppm}$ associative polymer can raise the oil recovery for the $6.52 \%$ than waterflooding and for the $1.67 \%$ above the partially hydrolyzed polyacrylamide.

Open Access This article is distributed under the terms of the Creative Commons Attribution 4.0 International License (http://creativeco mmons.org/licenses/by/4.0/), which permits unrestricted use, distribution, and reproduction in any medium, provided you give appropriate credit to the original author(s) and the source, provide a link to the Creative Commons license, and indicate if changes were made.

\section{References}

Akbari S, Mahmood SM, Tan IM et al (2017) Experimental investigation of the effect of different process variables on the viscosity of sulfonated polyacrylamide copolymers. J Pet Explor Prod Technol. https://doi.org/10.1007/s13202-016-0244-8

Aktas F, Clemens T, Castanier L, Kovscek AR (2008) Viscous oil displacement via aqueous associative polymers. Paper SPE 113264 presented at the SPE/DOE symposium on improved oil recovery, Tulsa, OK, 12-23 April. https://doi.org/10.2118/113264-MS. https://search.crossref.org/?q=10.2118\%2F113264-MS. https ://scholar.google.ru/scholar?hl=ru\&as_sdt $=0 \% 2 \mathrm{C} 5 \& \mathrm{q}=\mathrm{Visco}$ us+Oil+Displacement+via+Aqueous+Associative+Polym ers\&btnG=

Alexis D, Varadarajan D, Kim DH, Winslow G, Malik T (2016) Evaluation of innovative associative polymers for low concentration polymer flooding. Society of Petroleum Engineers. https://doi.org/10.2118/179696-MS. https://search.crossref. org/?q=10.2118\%2F179696-MS. https://scholar.google.ru/schol ar?hl=ru\&as_sdt=0\%2C5\&q=Evaluation+of+Innovative+Assoc
iative+Polymers+for+Low + Concentration + Polymer+Flood ing \&btnG $=$

Al-Taq AA, Nasr-El-Din HA, Lajami R et al (2007) Effective acid diversion and water control in carbonate reservoirs using an associative polymer treatment: case histories from Saudi Arabia. Presented at the SPE annual technical conference and exhibition, Anaheim, California, 11-14 November. SPE-109714-MS. https://doi.org/10.2118/109714-MS. https://search.crossref. org/?q=10.2118\%2F109714-MS. https://scholar.google.ru/ scholar?hl=ru\&as_sdt $=0 \% 2 \mathrm{C} 5 \& \mathrm{q}=$ Effective+Acid+Diver sion+and +Water+Control+in+Carbonate+Reservoirs+Using + an + Associative + Polymer+Treatment $\% 3 \mathrm{~A}+\mathrm{Case}+$ Histo ries+From+Saudi+Arabia.\&btnG $=$

Azad MS, Trivedi JJ (2017) Injectivity behavior of copolymer and associative polymers decoded using extensional viscosity characterization: effect of hydrophobic association. Society of Petroleum Engineers. https://doi.org/10.2118/185668-MS. https://searc h.crossref.org/?q=10.2118\%2F185668-MS. https://scholar.googl e.ru/scholar?hl=ru\&as_sdt $=0 \% 2 \mathrm{C} 5 \& \mathrm{q}=$ Injectivity + Behav ior+of+Copolymer+and+Associative+Polymers+Decod ed+Using+Extensional+Viscosity+Characterization\%3A+Effec $\mathrm{t}+\mathrm{of}+$ Hydrophobic+Association.\&btnG $=$

Basnieva IK, Zolotukhin AB, Eremin NA, Udovina EF (1994) Comparative analysis of successful application of EOR in Russia and CIS. Society of Petroleum Engineers. https://doi.org/10.2118/28002 -MS. https://search.crossref.org/?q=10.2118\%2F28002-MS. https://scholar.google.com/citations? user=u 1otx ykAAA AJ\#d=gs_md_cita-d\&u=\%2Fcitations\%3Fview_op\%3Dvie w_citation\%26hl\%3Dru\%26user\%3Du1 otxykAAAAJ\%26cst art\%3D100\%26pagesize\%3D100\%26citation_for_view\%3Du1o txykAAAAJ\%3Au-x6o8ySG0sC\%26tzom\%3D-180. https://www. researchgate.net/publication/254501874_Comparative_Analysis_ of_Successful_Application_of_EOR_in_Russia_and_CIS

Cheraghian G, Khalili Nezhad SS, Kamari M et al (2015) Effect of nanoclay on improved rheology properties of polyacrylamide solutions used in enhanced oil recovery. J Pet Explor Prod Technol. https://doi.org/10.1007/s13202-014-0125-y

Delamaide E (2018) Polymers and their limits in temperature, salinity and hardness: theory and practice. Society of Petroleum Engineers. https://doi.org/10.2118/192110-MS. https ://search.crossref.org/?q=10.2118\%2F192110-MS. https:// 
scholar.google.ru/scholar?hl=ru\&as_sdt=0\%2C5\&q=Polym ers + and + Their + Limit s+in + Temperature $\% 2 \mathrm{C}+$ Salin ity+and+Hardness\%3A+Theory+and+Practice \&btnG=

Denney D (2012) Rheology of a new sulfonic associative polymer in porous media. Society of Petroleum Engineers. https ://doi.org/10.2118/0112-0067-JPT. https://search.cross ref.org/?q=10.2118\%2F0112-0067-JPT. https://schol ar.google.ru/scholar?hl=ru\&as_sdt $=0 \% 2 \mathrm{C} 5 \& \mathrm{q}=\mathrm{Rheol}$ ogy + of $+\mathrm{a}+\mathrm{New}+$ Sulfonic + Associative + Polymer+in+Porou $\mathrm{s}+$ Media\&btnG $=$

Doe PH, Moradi-Araghi A, Shaw JE, Stahl GA (1987) Development and evaluation of EOR polymers suitable for hostile environments part 1: copolymers of vinylpyrrolidone and acrylamide. Society of Petroleum Engineers. https://doi.org/10.2118/14233 -PA. https://search.crossref.org/?q=10.2118\%2F14233-PA. https://scholar.google.ru/scholar?hl=ru\&as_sdt=0,5\&q=Devel opmen $\mathrm{t}+$ and + Evaluation + of + EOR + Polymers +Suita $\mathrm{ble}+$ for + Hostile + Environments + Part $+1 \% 3 \mathrm{~A}+\mathrm{Copol}$ ymer+of+Vinylpyrrolidone+and+Acrylamide

Dupuis G, Tabary R, Grassl B (2010) How to get the best out of hydrophobically associative polymers for IOR? New experimental insights. Society of Petroleum Engineers. https://doi.org/10.2118/129884-MS. https://search.cross ref.org/?q=10.2118\%2F129884-MS. https://scholar.googl e.ru/scholar?hl=ru\&as_sdt $=0 \% 2 \mathrm{C} 5 \& \mathrm{q}=\mathrm{How}+\mathrm{to}+\mathrm{Get}+\mathrm{t}$ he+Best+Out+of+Hydrophobically +Associative+Polym ers +for+IOR\%3F+New+Experimental+Insights.\&btnG=

Eremin NA, Nazarova LA (2001) Enhanced oil recovery methods (Edited by prof. Igor T. Mischenko). Gubkin Russian State University of Oil and Gas, Moscow. https://www.researchga te.net/publication/297392172_Enhanced_Oil_Recovery_Metho ds. https://istina.msu.ru/publications/book/20226897/. http:// ipng.ru/uf/EreminNA_NazarovaLN_Enhanced_Oil_Recov ery_Methods.pdf

Gogoi S, Gogoi SB (2019) Review on microfluidic studies for EOR application. J Pet Explor Prod Technol. https://doi.org/10.1007/ s13202-019-0610-4

Guo Y, Zhang J, Zhang X, Hu J, Wang W, Liang Y (2018) Investigation and application of an associative polymer-surfactant binary system for a successful flooding pilot in a high-temperature, high-salinity, ordinary heavy oil reservoir. Society of Petroleum Engineers. https://doi.org/10.2118/190411-MS. https:// search.crossref.org/?q=10.2118\%2F190411-MS. https://schol ar.google.ru/scholar?hl=ru\&as_sdt $=0 \% 2 \mathrm{C} 5 \& \mathrm{q}=$ Investigat ion+and+Application + of + an + Associative+Polymer-Surfa ctant+Binary+System + for $+\mathrm{a}+$ Successful+Flooding + Pilot + in + a + High-Temperature $\% 2 \mathrm{C}+$ High-Salinity $\% 2 \mathrm{C}+$ Ordin ary+Heavy+Oil+Reservoir.\&btnG=

Han X, Zhang G, Yu J, Chen Z, Kurnia I (2018) An investigation of retention and unusually high apparent viscosity of hydrophobically associative polymer in porous media. Society of Petroleum Engineers. https://doi.org/10.2118/190330-MS. https:// search.crossref.org/?q=10.2118\%2F190330-MS. https://schol ar.google.ru/scholar?hl=ru\&as_sdt $=0 \% 2 \mathrm{C} 5 \& \mathrm{q}=\mathrm{An}+$ Investigat ion+of+Retention+and+Unusually+High+Apparent+Visco sity+of+Hydrophobically+Associative+Polymer+in+Porou $\mathrm{s}+$ Media\&btnG=

Lake LW (1996) Enhanced oil recovery. Prentice Hall, Englewood Cliffs

Leblanc T, Braun O, Thomas A, Divers T, Gaillard N, Favero C (2015) Rheological properties of stimuli-responsive polymers in solution to improve the salinity and temperature performances of polymer-based chemical enhanced oil recovery technologies. Society of Petroleum Engineers. https ://doi.org/10.2118/174618-MS. https://search.crossref. org/?q=10.2118\%2F174618-MS. https://scholar.google.ru/ scholar?hl=ru\&as_sdt $=0 \% 2 \mathrm{C} 5 \& \mathrm{q}=$ Rheological+Properties +of+Stimuli-Responsive+Polymers+in+Solution+to+Impro $\mathrm{ve}+$ the + Salinity + and + Temperature + Performances+of+Polym er-Based+Chemical+Enhanced+Oil+Recovery+Technologi es\&btnG=

Levitt D, Pope GA (2008) Selection and screening of polymers for enhanced-oil recovery. Society of Petroleum Engineers. https://doi.org/10.2118/113845-MS. https://search.crossref. org/?q=10.2118\%2F113845-MS. https://scholar.google.ru/ scholar?hl=ru\&as_sdt $=0 \% 2 \mathrm{C} 5 \& \mathrm{q}=$ Selection + and + Scree ning+of+Polymers+for+Enhanced-Oil+Recovery\&btnG=

Lv Y, Feng Y, Wang Z, Li A, Zhang Q, Huang B, Zuo J, Ren Z, Chen Y (2017) Hydrophobically associating polymer water-inoil emulsions used in multi-pad fracking for tight oil reservoir: the first example in China. Society of Petroleum Engineers. https://doi.org/10.2118/184577-MS. https://search.crossref. org/?q=10.2118\%2F184577-MS. https://scholar.google.ru/ scholar?hl=ru\&as_sdt $=0 \% 2 \mathrm{C} 5 \& \mathrm{q}=$ Hydrophobically + Assoc iating+Polymer+Water-in-Oil+Emulsions+Used+in+Multi -pad+Fracking +for+Tight+Oil+Reservoir\%3A+The+First + Example+in+China\&btnG $=$

Moradi-Araghi A, Cleveland DH, Westerman IJ (1987) Development and evaluation of EOR polymers suitable for hostile environments: II-copolymers of acrylamide and sodium AMPS. Society of Petroleum Engineers. https://doi.org/10.2118/16273-MS. https://search.crossref.org/?q=10.2118\%2F16273-MS. https:// scholar.google.ru/scholar?hl=ru\&as_sdt $=0 \% 2 \mathrm{C} 5 \& \mathrm{q}=$ Devel opmen $\mathrm{t}+$ and + Evaluation + of + EOR + Polymers +Suita $\mathrm{ble}+$ for + Hostile + Environments $\% 3 \mathrm{~A}+\mathrm{II}-\mathrm{Copolymers}$ + of +Acrylamide+and+Sodium+AMPS\&btnG=

Nunez Garcia W, Leal Jauregui JA, Malik AR, Al-Abdulmohsin YA, Izquierdo GA, Al-Mumen M (2010) Achieving successful diversion in acid stimulation treatments: case study of excellent results achieved using APT (associative polymer treatment) in highly heterogeneous carbonate reservoirs in Saudi Arabia. Society of Petroleum Engineers. https ://doi.org/10.2118/125955-MS. https://search.crossref. org/?q=10.2118\%2F125955-MS. https://scholar.google.ru/schol ar?hl=ru\&as_sdt $=0 \% 2 \mathrm{C} 5 \& \mathrm{q}=$ Achieving + Successful+Diver sion+in+Acid+Stimulation+Treatments $\% 3 \mathrm{~A}+\mathrm{Case}+$ Study +of +Excellent + Results + Achieved + Using + APT $+\% 28$ Ass ociative+Polymer+Treatment $\% 29+$ in + Highly + Heterogene ous +Carbonate+Reservoirs+in + Saudi+Arabia\&btnG $=$

Reichenbach-Klinke R, Stavland A, Strand D (2016) Can associative polymers reduce the residual oil saturation? Presented at the SPE EOR conference at oil and gas, West Asia, Muscat, 21-23 March. SPE 179801-MS. http://dx.doi.org/10.2118/17980 1-MS. https://search.crossref.org/?q=10.2118\%2F179 801-MS. https://scholar.google.ru/scholar?hl=ru\&as $\mathrm{sdt}=0 \% 2 \mathrm{C} 5 \& \mathrm{q}=\mathrm{Can}+$ Associative + Polymers + Reduc $\mathrm{e}+$ the+Residual+Oil+Saturation $\% 3 \mathrm{~F} \& \mathrm{btnG}=$

Skauge T, Djurhuus K, Reichenbach-Klinke R (2018) Visualization of heavy oil mobilization by associative polymer. Society of Petroleum Engineers. https://doi.org/10.2118/190770-MS. https://searc h.crossref.org/?q=10.2118\%2F190770-MS. https://scholar.googl e.ru/scholar?hl=ru\&as_sdt $=0 \% 2 \mathrm{C} 5 \& \mathrm{q}=$ Visualization + of + Heavy +Oil+Mobilization+by+Associative+Polymer\&btnG=

Tripathi A, Tam KC, McKinley GH (2006) Rheology and dynamics of associative polymers in shear and extension: theory and experiments. Macromolecules 39(5):1981-1999. https://doi. org/10.1021/ma051614x

Publisher's Note Springer Nature remains neutral with regard to jurisdictional claims in published maps and institutional affiliations. 